\title{
Italian space scientists face more upheaval
}

Rome. The Italian Space Agency (ASI) could be shaken up for the second time in just over a year if Stefano Podestá, the minister for research and universities, has his way - and the Italian coalition government survives its current turmoil. Earlier this month, the senate committee for industrial affairs approved a bill, drawn up by Podestá, to install for one year an amministratore unico - a single administrator — with a brief to restructure the agency.

The move has precipitated a fierce battle in parliament over Podestá's motives, while scientists are concerned that uncertainty over the agency's short-term future could mean that the distribution of grants for space research once again grinds to a halt.

It is the second time Podestá has tried to change the way ASI is run. In November he tried to push a decree through cabinet to achieve this objective. But the move failed on the grounds that a decree, which avoids a parliamentary debate, can only be used in emergencies.

Podestá has subsequently tried to rush his bill through parliament. He successfully arranged for it to be approved by the senate industrial committee, with the result that it did not have to be discussed by the full senate. However, following pressure from parliamentarians who want to ensure that it gets a proper debate, the bill will now be discussed in detail by the chamber of deputies, rather than just by a committee.

Two hostile parliamentary questions have been put, one challenging the appropriateness of the proposed restructuring, the other asking Podestá whether his motive in rushing through this legislation was partly to allow him, in return for a previous favour, to appoint the current ASI director general, Mario Calamia, to the new post as the sole administrator.

ASI has been plagued with problems since it was set up in 1988. It has always been financially disorganized, and became

\section{Italy drops decision to quit EMBL}

Munich. The Italian government has formally announced that it is withdrawing its notice to leave the European Molecular Biology Laboratory (EMBL), based in Heidelberg, at the end of this year.

Italy's notice that it was leaving EMBL was based on its unhappiness over the relatively low number of Italian staff scientists at EMBL, despite the fact that it pays around 16 per cent of the laboratory's annual budget.

The decision to return to the fold, which has been expected for several weeks, is linked to plans to establish a joint European Union/EMBL mouse gene repository near Rome (see Nature 372, 305; 1994). A. A. deeply embroiled in corruption scandals last year, while an internal dispute over the amount of money ASI is supposed to give to basic research had blocked funding for space research for nearly two years.

In August 1993, the government approved a decree to install a commissioner to set ASI's administrative and financial affairs in order, and money started to flow to space scientists. But the commissioner was unable to get ASI's books to balance.

The situation appeared to be more stable when the then research minister, Umberto Colombo, appointed Giorgio Fiocco, an atmospheric physicist from Rome University, as ASI president last March, a few days before the general elections. Fiocco belatedly appointed a new science committee in the summer, and this convened last month to finalize allocation of the 1994 budget, which has remained unapproved.

But Podestá is now said to want to replace Fiocco with his own candidate rumoured to be Calamia, who was appointed by Podestá in early summer. He has never discussed ASI's affairs with Fiocco, even though he regularly meets the heads of Italy's other research organizations.

Podestá says that turning ASI into "a healthy body for space research" is a necessary part of the overall restructuring of Italy's research bodies (see Nature $\mathbf{3 7 2}$, 393 ; 1994). A major task of the new administrator will be to try to disentangle ASI's financial problems.
In the early $1990 \mathrm{~s}, \mathrm{ASI}$ took on more commitments than it could afford. As a result, either some existing contracts with Italian industry will have to be revised, or more money must be provided by the government to fulfil the agency's legal obligations. According to the bill before parliament, the single administrator will be helped in tackling this issue by three economists from the treasury.

But scientists are concerned about several aspects of the bill. In particular, they are worried that the new temporary structure being proposed for the administration of the agency would give an excessive amount of power to the research minister.

According to the bill, the single administrator will be appointed by the minister. The latter will also have the power to decide how much money is allocated to basic science (the current law stipulates that this should be 15 per cent of Italy's space budget), based on the advice of a committee of "three experts in research and two economists", each appointed by the minister. (A new science committee will be appointed directly by the administrator.)

In addition, Podestá plans to appoint a separate committee to investigate the activities of ASI between 1988 and May this year. This covers the period in which the former government's commissioner was in place, and will presumably work in parallel with a current court inquiry into ASI's affairs.

Alison Abbott

\section{'Fossil tree' reveals full splendour}

Sydney. The full-grown version ( right) of a prehistoric pine tree found in August in a secluded rain forest in the Wollemi National Park west of Sydney (see also page 712). According to scientists at the Royal Botanic Gardens in Sydney, the Wollemi pine is a newly discovered genus whose nearest relatives died out in the Jurassic and Cretaceous eras 195-140 million and 140-65 million years ago respectively.

The trees, about $\mathbf{4 0}$ metres tall and with a girth of three metres, are covered in a dense, waxy foliage, and have "a distinct nobbly bark that makes them look like they are coated with bubbly brown chocolate".

Chris Hartcher, environment minister for New South Wales, has described the discovery as "the Australian Christmas tree". Scientists have compared the significance of the discovery to that of the coelacanth discovered off the coast of Madagascar in 1948. 